\title{
Gadd45b deficiency promotes premature senescence and skin aging
}

\author{
Andrew Magimaidas ${ }^{1}$, Priyanka Madireddi ${ }^{1}$, Silvia Maifrede $^{1}$, Kaushiki Mukherjee $^{1}$, \\ Barbara Hoffman ${ }^{1,2}$ and Dan A. Liebermann ${ }^{1,2}$ \\ ${ }^{1}$ Fels Institute for Cancer Research and Molecular Biology, Temple University School of Medicine, Philadelphia, PA, USA \\ ${ }^{2}$ Department of Medical Genetics and Molecular Biochemistry, Temple University School of Medicine, Philadelphia, PA, USA \\ Correspondence to: Dan A. Liebermann, email: lieberma@temple.edu \\ Keywords: Gadd45b, senescence, oxidative stress, DNA damage, cell cycle arrest, Gerotarget \\ Received: March 17, $2016 \quad$ Accepted: April 12, $2016 \quad$ Published: April 20, 2016
}

ABSTRACT

The GADD45 family of proteins functions as stress sensors in response to various physiological and environmental stressors. Here we show that primary mouse embryo fibroblasts (MEFs) from Gadd45b null mice proliferate slowly, accumulate increased levels of DNA damage, and senesce prematurely. The impaired proliferation and increased senescence in Gadd45b null MEFs is partially reversed by culturing at physiological oxygen levels, indicating that Gadd45b deficiency leads to decreased ability to cope with oxidative stress. Interestingly, Gadd45b null MEFs arrest at the G2/M phase of cell cycle, in contrast to other senescent MEFs, which arrest at G1. FACS analysis of phospho-histone $\mathrm{H3}$ staining showed that Gadd45b null MEFs are arrested in G2 phase rather than M phase. H2O2 and UV irradiation, known to increase oxidative stress, also triggered increased senescence in Gadd45b null MEFs compared to wild type MEFs. In vivo evidence for increased senescence in Gadd45b null mice includes the observation that embryos from Gadd45b null mice exhibit increased senescence staining compared to wild type embryos. Furthermore, it is shown that Gadd45b deficiency promotes senescence and aging phenotypes in mouse skin. Together, these results highlight a novel role for Gadd45b in stress-induced senescence and in tissue aging.

\section{INTRODUCTION}

Gadd45a, Gadd45b and Gadd45g constitute a family of genes, which encode for small (18 kDa) evolutionarily conserved proteins that are highly homologous to each other. Despite marked similarities, these genes are regulated in a differential manner and exhibit functional diversity. They play a pivotal role in regulating diverse cellular functions such as cell cycle control, survival, and apoptosis and are regulated by the nature of the stress stimulus encountered, its magnitude, and the cell type. Gadd45a, Gadd45b and Gadd45g have been implicated in cell cycle arrest [1-4], DNA repair [5], apoptosis [6], innate immunity [7] and genomic stability [8]. GADD45 proteins have been shown to stimulate the p38-c-Jun N-terminal kinase (JNK) mitogen-activated protein (MAP) kinase pathways in response to stress and thereby sensitize cells to apoptosis, survival or growth arrest [9]. GADD45 proteins were also shown to regulate cell cycle checkpoints in response to genotoxic stress, notably the G2/M checkpoint [10-11]. Furthermore, Gadd45b has also been identified as a transcriptional target of NF$\kappa \mathrm{B}$, encoding a potent and selective inhibitor of the JNK MAPK pathway and, therefore, of apoptosis [12-13].

Cellular senescence, first identified as a process that limits the proliferation or growth of human cells in culture [14] is now recognized as a crucial tumor suppressor mechanism and formidable barrier to malignant progression [15]. It was also shown to be induced by a variety of potentially oncogenic stimuli, such as telomere shortening, DNA damage, oxidative stress, and oncogene expression [16-17]. MEFs are primary cells with limited life-span, that senesce in culture [18]. The senescence observed in primary MEFs is at least in 
part due to the stress of them being placed in culture, particularly, hyperoxic culture conditions, which results in accumulation of DNA damage [19-21]. Several studies have revealed a role for Gadd45a in senescence. Gadd45a null MEFs do not undergo senescence in response to oncogenic H-ras [22]. Interestingly, in a mouse model of mammary tumorigenesis, loss of Gadd45a in the presence of Myc was shown to lead to increased senescence whereas loss of Gadd45a in the presence of Ras leads to decreased senescence [23, 24]. Although Gadd45a has been shown to play a significant role in regulating cellular senescence in response to stress, the role of Gadd45b has not been studied. Thus, given the similarities and diversity among the Gadd45 family of genes, it was of interest, to investigate the role of Gadd45b in senescence.

In the current study, we show that mouse embryonic fibroblasts (MEFs) lacking Gadd45b exhibit impaired proliferation, a G2 cell-cycle arrest and premature senescence. We also show that Gadd45b null cells are more sensitive to hyperoxic stress and have higher levels of DNA damage than Gadd45 $b^{+/+}$cells. Furthermore, Gadd45b null MEFs arrest at the G2/M phase of cell cycle, with impaired G2/M cell-cycle progression, in contrast

A

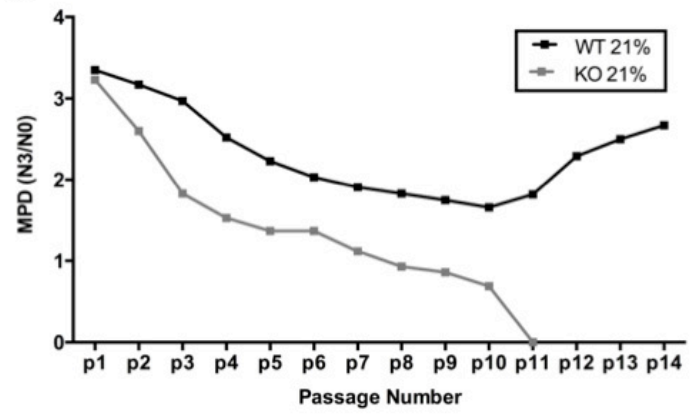

B

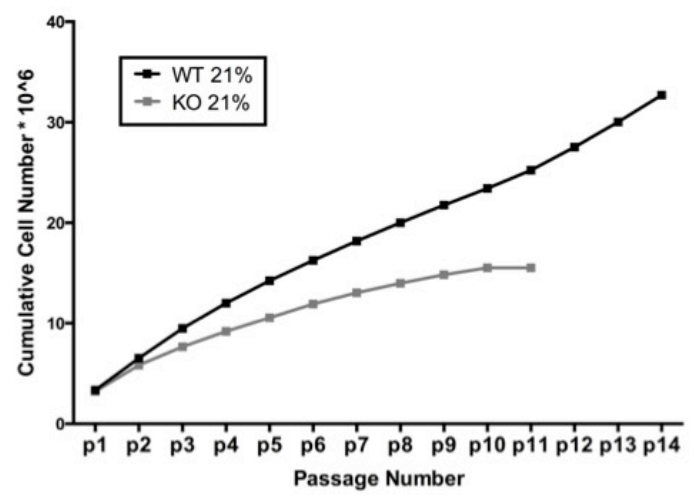

to other senescent MEFs that arrest at G1. Notably, we show that loss of Gadd $45 \mathrm{~b}$ promotes senescence and aging phenotypes in the skin providing in vivo evidence for increased senescence in $G a d d 45 b^{-/-}$mice and suggesting a hitherto unidentified role for Gadd45b in regulating stressinduced cellular senescence.

\section{RESULTS}

\section{Decreased proliferation and premature senescence in Gadd45 $b^{-/-}$MEFs}

${\text { Gadd } 45 b^{+/+}}_{\text {(WT) and Gadd45b }}^{-/}$(KO) MEFs were subjected to serial passage using the $3 \mathrm{~T} 3$ protocol $[21,25,26]$ under standard culture conditions, which included atmospheric (20\%) oxygen. While the Gadd45b $b^{+/+}$MEFs exhibited characteristic biphasic growth kinetics seen in mouse embryonic fibroblasts, all Gadd $45 b^{-/}$MEFs analyzed showed significantly reduced proliferation (Figure 1A and 1B). This is in striking contrast with Gadd45a $a^{-/}$MEFs, which showed increased
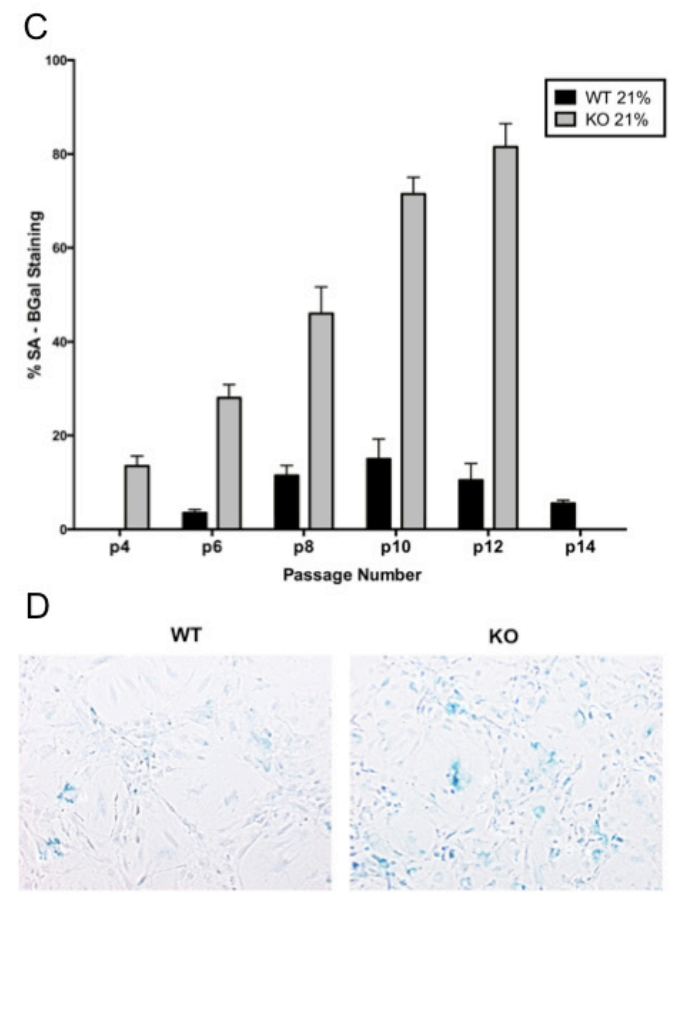

Figure 1: Decreased proliferation and premature senescence of Gadd45b $^{-/-}$MEFs. A. Gadd45b GHT $^{+/+}$solid black) and Gadd $45 b^{-/}$(KO - solid grey) MEFs were cultured at 21\% oxygen continuously for 14 passages. Cells were split every 3 days, and the total numbers of cells were counted and mean population doublings (MPD) were determined. B. Cumulative cell number is plotted against passage number. C. $G a d d 45 b^{+/+}$and $G a d d 45 b^{-/}$MEFs were stained for SA- $\beta$-gal at each passage. SA- $\beta$-gal positive cells were counted in at least 10 fields from triplicate plates. A quantification of SA- $\beta$-gal positive Gadd45b $b^{+/+}$(solid black) and Gadd45b $b^{-/}$(solid grey) MEFs is shown for different passages. D. Representative images of $\mathrm{Gadd}_{45} b^{+/+}$and $\mathrm{Gadd} 45 b^{-/}$MEFs stained for SA- $\beta$-gal at passage 9. 
cell proliferation (Unpublished data). Furthermore, in all MEF cell cultures analyzed, loss of Gadd45b was shown to result in premature and increased senescence, as determined by Senescence-associated $\beta$-galactosidase (SA- $\beta$-gal) staining (Figure 1C and 1D).

It is known that primary MEFs are sensitive to oxidative stress in culture [19]. Hence, to test whether exposure to hyperoxia might be a factor in the premature senescence of $\mathrm{Gad}_{\mathrm{a}} 45 \mathrm{~b}^{-/} \mathrm{MEFs}$, these MEFs were cultured in the presence of $3 \%$ oxygen, which is known to be similar to the physiologic oxygen condition in vivo. MEFs were prepared from Gadd $45 b^{+/+}$and Gadd $45 b^{-/}$embryos, and cultured under two different conditions, one at $21 \% \mathrm{O}_{2}$ and the other under physiologically relevant low oxygen $\left(3 \% \mathrm{O}_{2}\right)$ conditions. As shown in Figure $2 \mathrm{~A}$ and $2 \mathrm{~B}$, it was observed that culturing cells under physiological oxygen conditions $\left(3 \% \mathrm{O}_{2}\right)$ resulted in a partial rescue of their

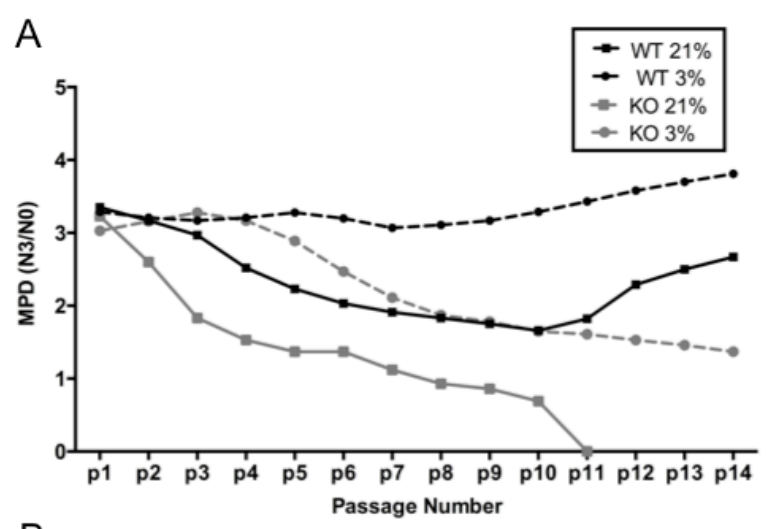

B

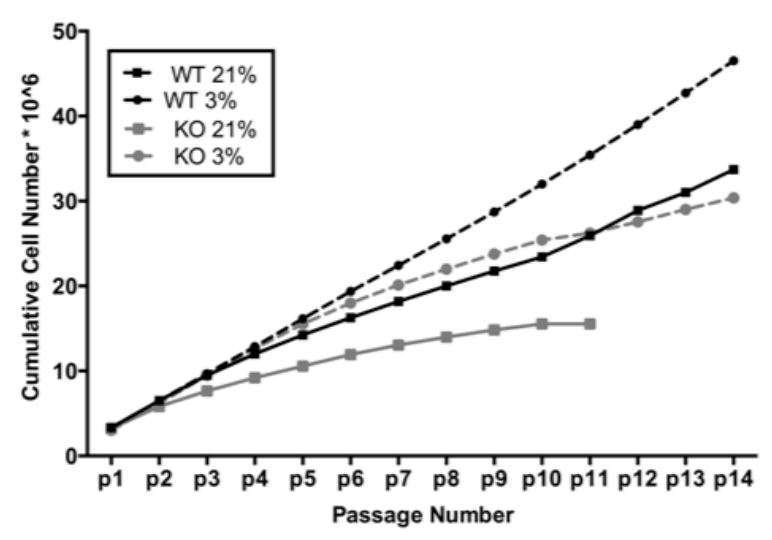

ability to proliferate. It should be noted, however, that Gadd $45 b^{+/+}$MEFs also proliferated faster in $3 \% \mathrm{O}_{2}$, and the proliferation rate of $\mathrm{Gadd} 45 b^{-/}$MEFs was still much lower than Gadd45 $b^{+/+}$MEFs. Also, SA- $\beta$-gal staining of Gadd $45 b^{-/}$MEFs was less at 3\% $\mathrm{O}_{2}$ compared to staining at $21 \% \mathrm{O}_{2}$ (Figure 2C) indicating that loss of Gadd45b leads to increased sensitivity to oxidative stress and other tissue-culture stressors leading to increased senescence.

It was next asked if oxidative stress modulates Gadd $45 b$ mRNA expression. Interestingly, we observed that the expression of Gadd45b in Gadd45b $b^{+/+}$MEFs progressively increased with passage numbers (Figure 2D). Also, Gadd45b mRNA levels were consistently higher in MEFs cultured at $21 \%$ oxygen compared to cells cultured in $3 \%$ oxygen indicating that Gadd $45 b$ expression is directly correlated to the level of oxidative stress.
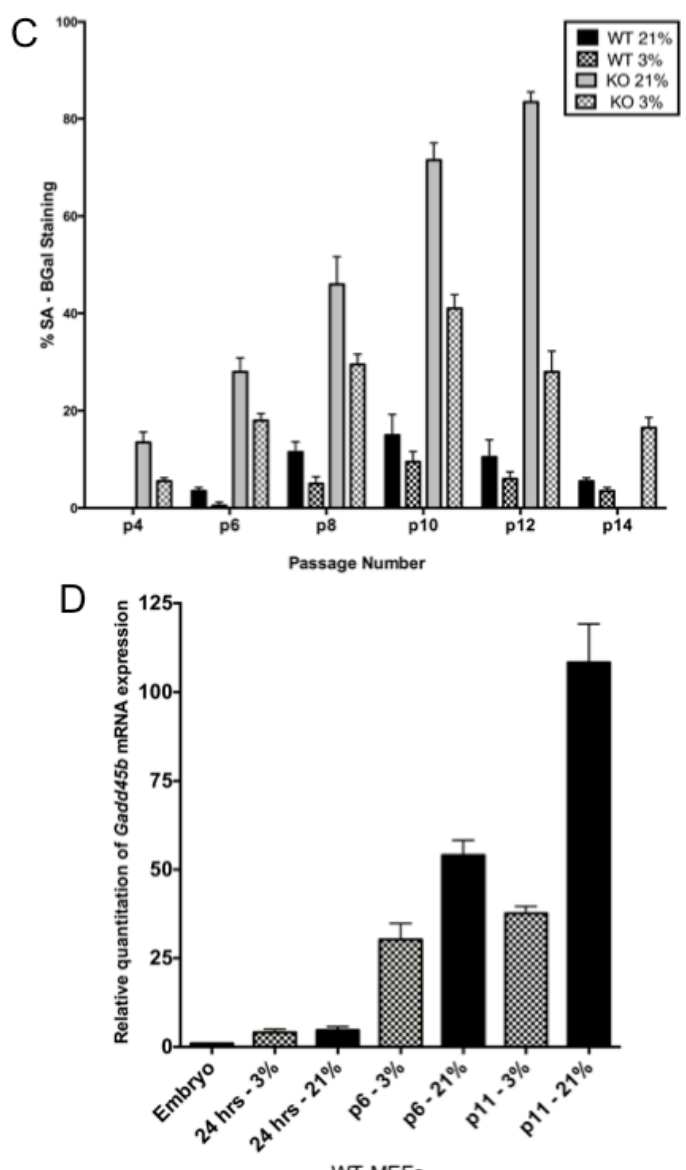

WT MEFs

Figure 2: Premature senescence associated with Gadd45b deficiency can be rescued, in part, by culture at low oxygen.

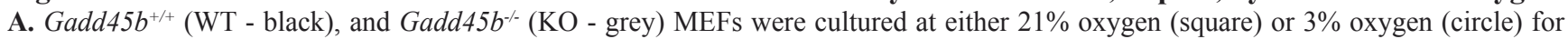
14 passages. Cells were split every 3 days, and the total numbers of cells were counted and mean population doublings (MPD) were determined. B. Cumulative cell number is plotted against passage number. C. Gadd45b $b^{+/+}$(black) and Gadd45b (grey) MEFs, cultured at either $21 \%$ oxygen (solid) or $3 \%$ oxygen (dotted) were stained for SA- $\beta$-gal at each passage. SA- $\beta$-gal positive cells were counted in at least 10 fields from triplicate plates. A quantification of SA- $\beta$-gal positive Gadd $45 b^{+/+}$and $G a d d 45 b^{--}$MEFs is shown for each passage. D. Gadd $45 b^{+/+}$MEFs were cultured at either $21 \%$ oxygen or $3 \%$ oxygen. Total RNA for each passage was analyzed by real time PCR for Gadd $45 \mathrm{~b}$ expression using taqman probe as described in Materials and methods. $18 \mathrm{~S}$ rRNA probe was used as an internal control. 


\section{Growth arrest of $\mathrm{Gadd45b}^{-/-}$MEFs is associated with defective G2/M cell-cycle progression}

To determine whether changes in cell cycle control accompany the decline in growth of Gadd45b MEFs, we compared the cell cycle profiles of $G a d d 45 b^{+/+}$ and Gadd $45 b^{-/}$MEFs. Surprisingly, Gadd $45 b^{-/}$MEFs displayed a gradual increase in the proportion of $\mathrm{G} 2 / \mathrm{M}$ cells with increased passage number compared to Gadd45 $b^{+/+}$MEFs (Figure 3). This finding is in striking contrast to other senescent MEFs, which normally arrest at G1 [27]. To delineate whether Gadd $45 b^{-/}$MEFs are arrested in G2 or M phase, we stained Gadd $45 b^{+/+}$and Gadd $45 b^{-/}$MEFs with Hoechst 33342 solution and scored for mitotic stage based on DNA morphology. The mitotic index of Gadd45 $b^{-\leftarrow}$ MEFs was lower than that of $\mathrm{Gadd}_{45} \mathrm{~b}^{+/+}$MEFs indicating that Gadd45 $b^{-/}$MEFs are arrested in G2 phase rather than M phase (Figure 4A). Nocodazole, a microtubule inhibitor used to arrest cells in mitosis, was used as an experimental control.
To further confirm this defect in $\mathrm{G} 2 / \mathrm{M}$ cell cycle progression, phospho-Histone $\mathrm{H} 3$ staining was performed. Histone $\mathrm{H} 3$ is phosphorylated at Ser 10 during M phase, but not at G2 [28]. Gadd45b $b^{-1}$ MEFs showed less phospho-Histone H3-positive cells than $\mathrm{Gadd}_{4} 5 b^{+/+} \mathrm{MEFs}$ (Figure 4B and 4C), indicating that loss of Gadd45b in MEFs results in an unexpected defect in G2/M cell-cycle progression.

\section{Increased p19 Arf -p53-p21 signaling and impaired Cdc2 expression in Gadd45 $b^{-/-}$MEFs}

Senescence in MEFs was shown to be associated with increased levels of p53 and its downstream target p21 as well as increased levels of p16 and p19 $9^{\mathrm{ARF}}[29]$. Thus it was of interest to determine the expression levels of p19 Arf -p53-p21 proteins in Gadd45b ${ }^{-/}$MEFs compared to Gadd $45 b^{+/+}$MEFs. It was found that Gadd $45 b^{-/}$MEFs showed increased levels of p16 ${ }^{\text {Ink4A }}, p 19^{\text {ARF }}, p 21, p 53$ and phospho-p53 proteins at earlier passage compared to

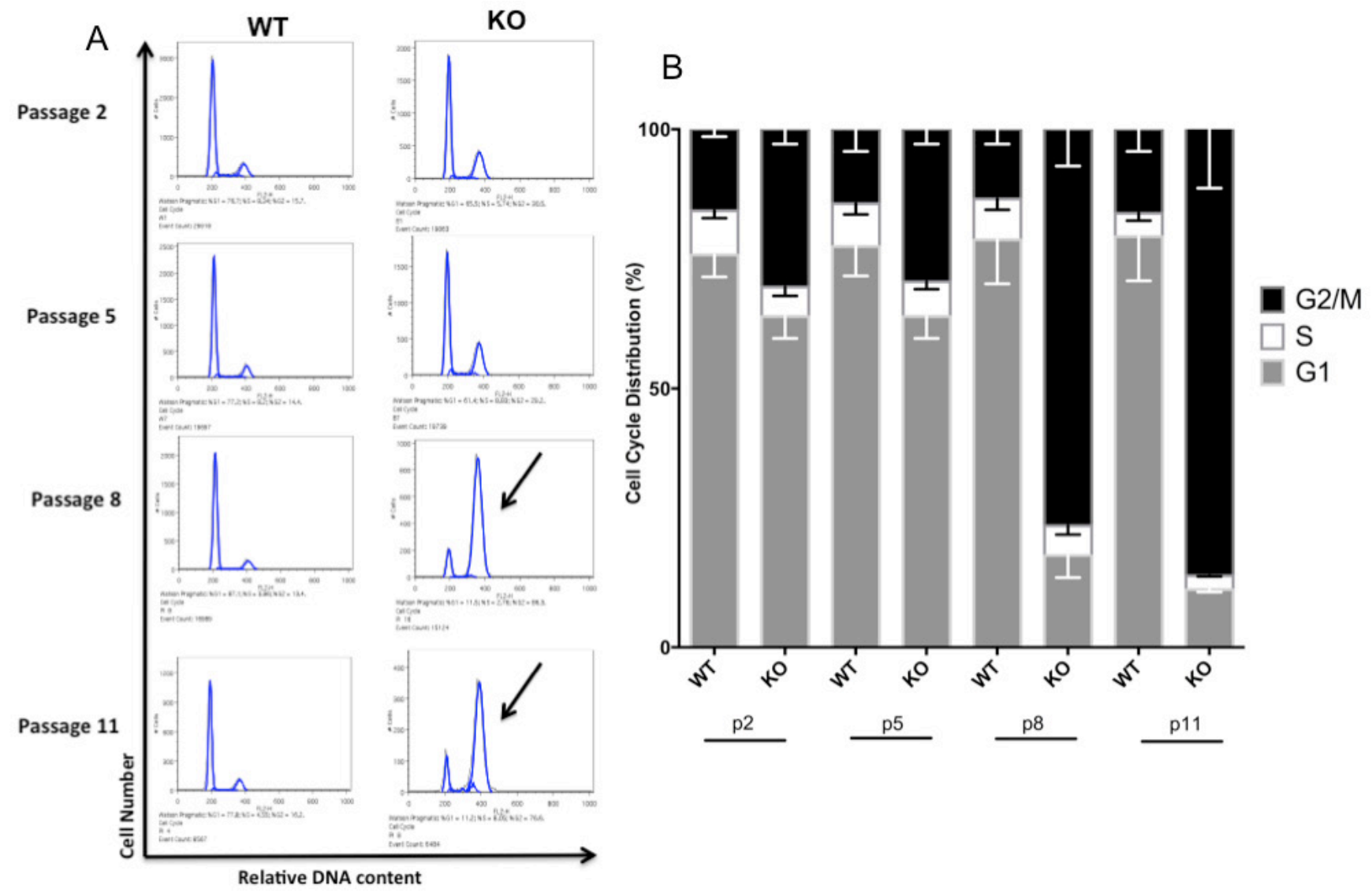

Figure 3: Loss of Gadd45b results in an accumulation in G2/M. A. Gadd45b $b^{+/}$(WT) and Gadd45b $b^{-/}$(KO) MEFs were cultured at $21 \%$ oxygen. Subconfluent cultures of cells were harvested at different passages and fixed prior to being stained with propidium iodide. DNA content was analyzed by flow cytometry. Arrow indicates enrichment of G2/M cells in late passage Gadd45b cultures. B. Quantitation of the fraction of cells in different cell cycle phases was done using FlowJo software. Bar diagram shows the $\%$ of cells present in different phases of cell cycle. 
Gadd45 $b^{+/+}$MEFs, in parallel with reduced growth rate and increased SA- $\beta$-gal staining (Figure 5A).

To investigate the mechanism through which Gadd45b regulates proliferation and $\mathrm{G} 2 / \mathrm{M}$ cell cycle progression, expression levels of the key G2/M transition complex, Cdc2/cyclin B1 were examined. While the expression of cyclin B1 was comparable between Gadd $45 b^{+/+}$and Gadd45b $b^{-/}$MEFs, intriguingly, a marked reduction in the expression of $\mathrm{Cdc} 2$ protein was observed

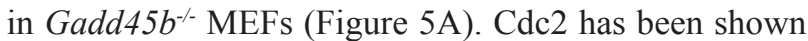
to be essential for $\mathrm{G} 2 / \mathrm{M}$ cell-cycle progression in multiple organisms [30]. As shown in Figure 5A, reduced expression of $\mathrm{Cdc} 2$ in $\mathrm{Gadd} 45 b^{-/}$MEFs correlated with reduced proliferation indicating that $\mathrm{Cdc} 2$ is a potential molecular target for Gadd45b regulated stress response. Furthermore, increased phosphorylation of stress-activated protein kinase/Jun-amino-terminal kinase (SAPK/JNK) was also observed in Gadd45b $b^{-/}$MEFs compared to Gadd $45 b^{+/+}$MEFs at late passage (Figure 5A). SAPK/JNK has been shown to regulate p53 dependent senescence [31]. To causally link increased activation of SAPK/ JNK in Gadd45b ${ }^{-/}$MEFs to increased tissue cultureinduced senescence, Gadd45 $b^{-/}$MEFs and Gadd45 $b^{+/+}$ MEFs at passage 6 were treated with JNK specific inhibitor, SP600125 for 48 hours and then stained for senescence-associated $\beta$-galactosidase (SA- $\beta$-gal) 6 days

A

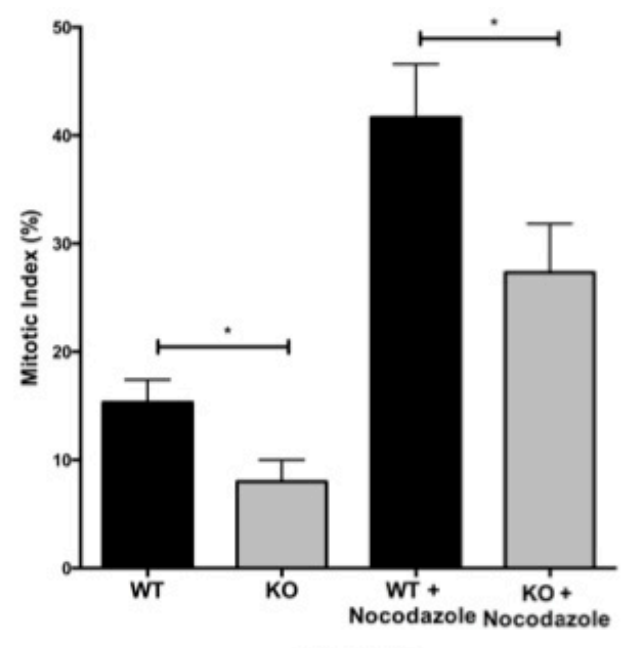

C
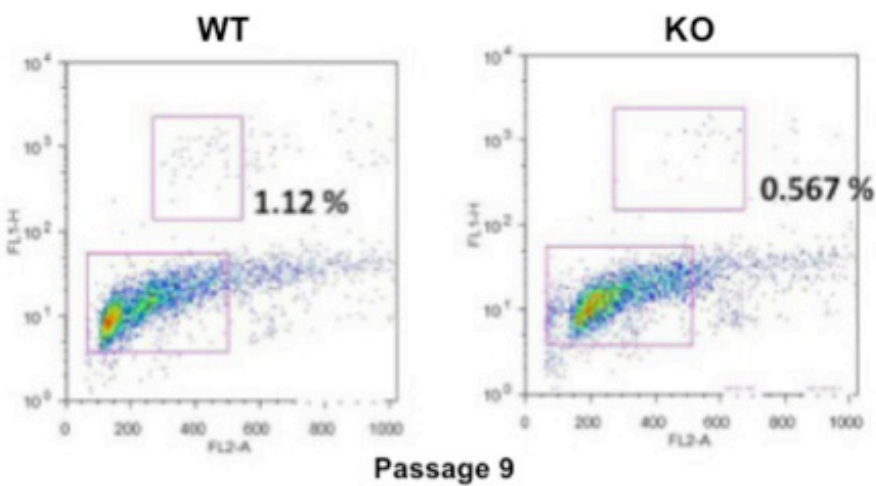

B
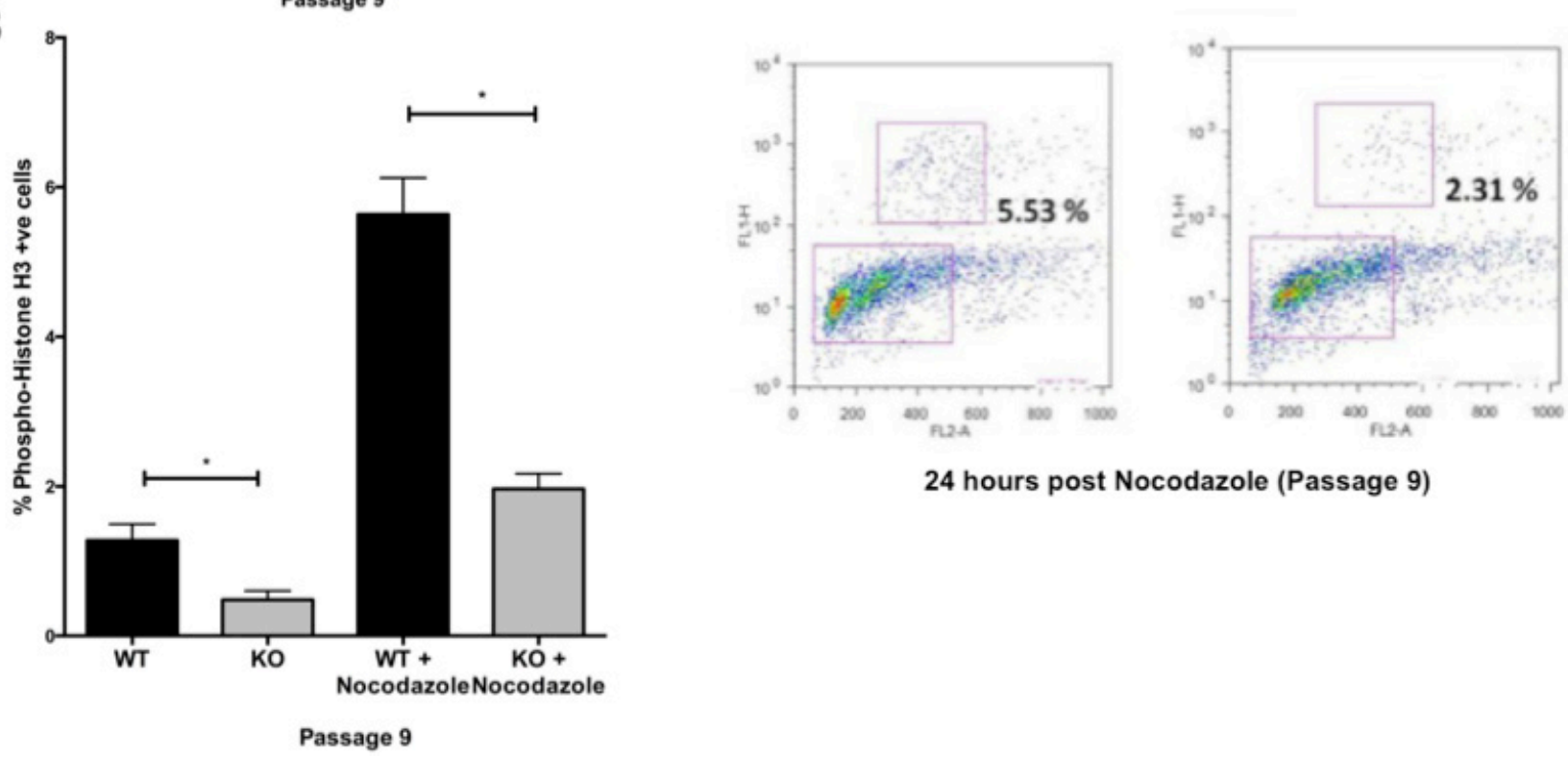

24 hours post Nocodazole (Passage 9)

Figure 4: Defective G2/M cell-cycle progression of Gadd45 $\boldsymbol{b}^{-/-}$MEFs. A. The mitotic index was determined in $\mathrm{Gadd}_{4}$. $b^{+/+}(\mathrm{WT})$ and $\mathrm{Gadd}_{45} b^{--}$(KO) MEFs cultured at 21\% oxygen at passage 9. Nocodazol treated cells were used as experimental control. B. Number of phosphorylated Histone H3- positive cells in Gadd45 $b^{+/+}$and Gadd45b $b^{-/}$MEFs cultured at 21\% oxygen (passage 9) using phosphospecific anti-Histone H3 (Ser10) antibodies. Mean values from three independent experiments are shown. C. Scatter plots show phospho-histone H3 (y axis) plotted against PI (DNA content, $\mathrm{x}$ axis), gated to quantify mitotic (phospho-histone H3 positive) cells (upper box). ${ }^{*} P<0.05$. 
later. As shown in Figure 5B, inhibition of SAPK/JNK in $\mathrm{Gadd}_{45 b^{+/+}}$and $\mathrm{Gadd} 45 b^{-/}$MEFs led to a decrease in SA- $\beta$-gal staining compared to untreated MEFs. Together, these data indicate that Gadd $45 b$ negatively regulates or limits tissue cultured induced senescence by modulating $\mathrm{SAPK} / \mathrm{JNK}, \mathrm{Cdc} 2$ and senescence signaling.

\section{Loss of Gadd45b results in accumulation of spontaneous DNA damage}

Cells with defective mitogen signaling generally accumulate in the G1 phase of cell cycle, whereas arrest in the G2/M phase of cell cycle is frequently indicative of a DNA damage response [32]. The premature senescence induced by hyperoxic stress in Gadd45b-/ MEFs was associated with accumulation of cells in the G2/M phase of the cell cycle (Figure 3), suggesting that this growth arrest might be associated with higher levels of endogenous DNA damage. To test whether there was increased DNA damage in $\mathrm{Gadd}_{45} \mathrm{~b}^{-/}$MEFs, cells were stained with an antibody that recognizes phosphorylated H2A.X (gH2AX) found specifically at repair foci. As shown in Figure 6A, an increase in phosphorylated $\mathrm{gH} 2 \mathrm{~A} . \mathrm{X}$ positive cells was observed in passage 8 Gadd $45 b^{-/}$MEFs compared to $\mathrm{Gadd}_{45} \mathrm{~b}^{+/+}$MEFs indicating that loss of Gadd45b leads to accumulation of DNA damage. Furthermore,

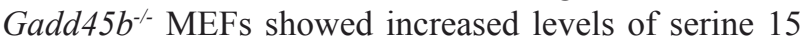
phosphorylation of p53 compared to Gadd $45 b^{+/+}$MEFs (Figure 5A), a modification induced in response to certain forms of DNA damage [33].

To further determine whether the growth arrest of $\mathrm{Gadd}_{4} \mathrm{~b}^{-/}$MEFs was associated with accumulation of oxidative DNA damage and directly assess the level of DNA damage on a single-cell basis, we performed comet assay. The assay was done under denaturing conditions to detect both single and double strand breaks and Olive Tail moment was used as a measure of both the smallest detectable size of migrating DNA (reflected in the comet tail length) and the number of relaxed/broken pieces (represented by the intensity of DNA in the tail). As shown in Figure 6B, significantly increased DNA damage, was observed in the Gadd $45 b^{-/-}$MEFs compared to Gadd $45 b^{+/+}$ MEFs at passage 8 .

Together, these data indicate that loss of Gadd45b leads to an accumulation of DNA damage induced by oxidative stress.

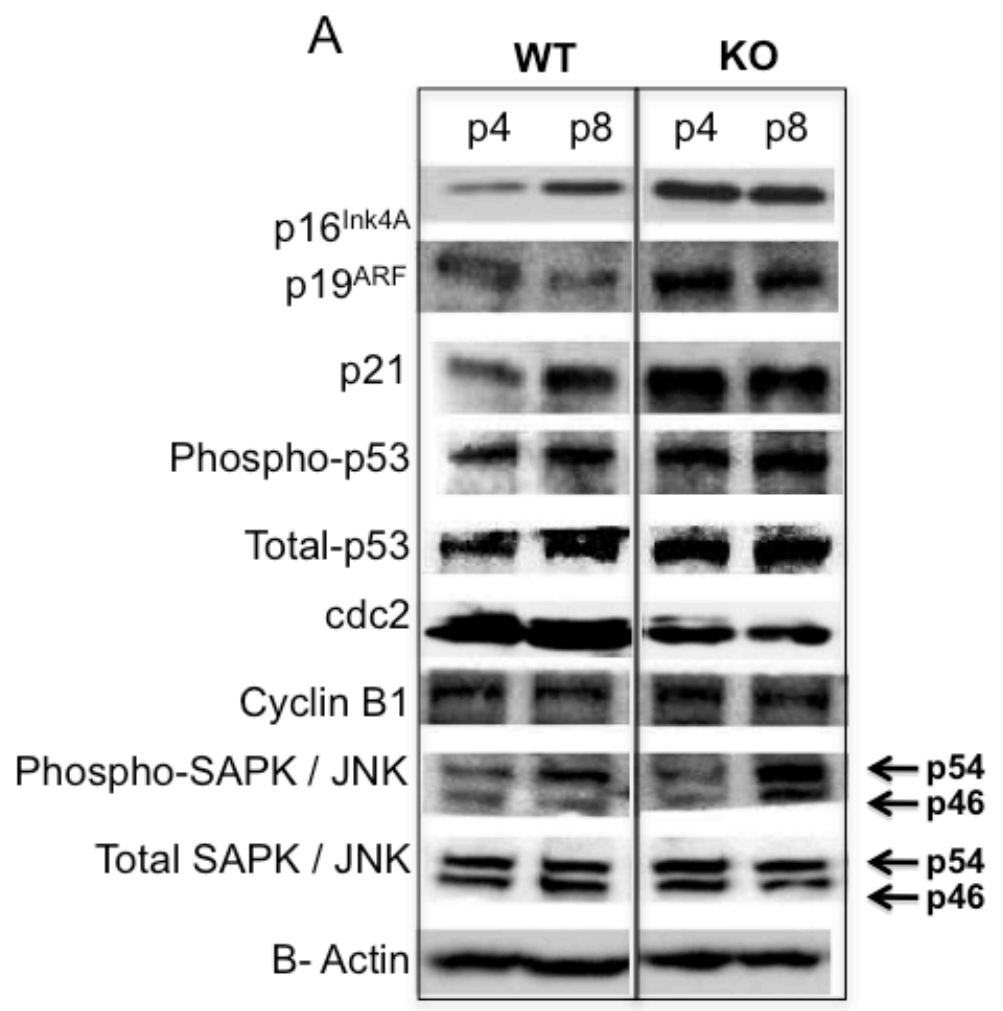

$\mathrm{B}$

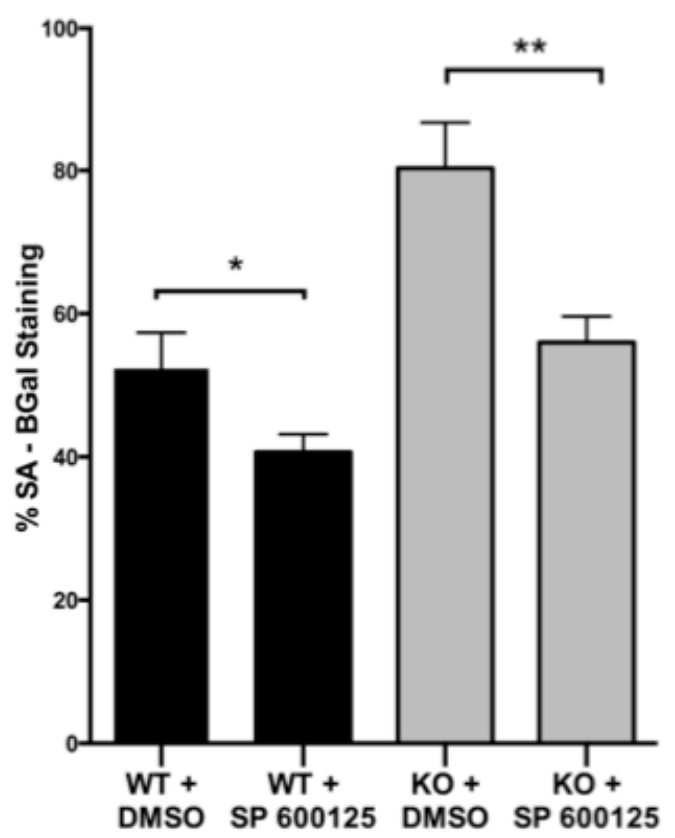

Figure 5: Signaling events involved in Gadd45 b Senescence. A. Western blotting analysis of p16 ${ }^{\text {Ink4A }}$, p19 ${ }^{\mathrm{ARF}}$, p21, Phospho-p53 (Ser15), Total-p53, cdc2, Cyclin B1, Phospho-SAPK/JNK (Thr183/Tyr185) and Total-SAPK/JNK expression in cell extracts prepared from $\mathrm{Gadd}_{45} b^{+/+}$(WT) and Gadd45b $b^{-/}$(KO) MEFs at different passages cultured at $21 \%$ oxygen. $\beta$-Actin was used as a loading control. B. Gadd $45 b^{+/+}$(black) and Gadd45b $b^{-/}$(grey) MEFs cultured at $21 \%$ oxygen (passage 6 ) were treated with vehicle $(0.1 \%$ DMSO) or JNK inhibitor, SP600125 for 24 hours and stained for SA- $\beta$-gal 5 days later. SA- $\beta$-gal positive cells were counted in at least 10 fields from triplicate plates. A quantification of SA- $\beta$-gal positive MEFs is shown. $* P<0.05, * * P<0.01$. 
A

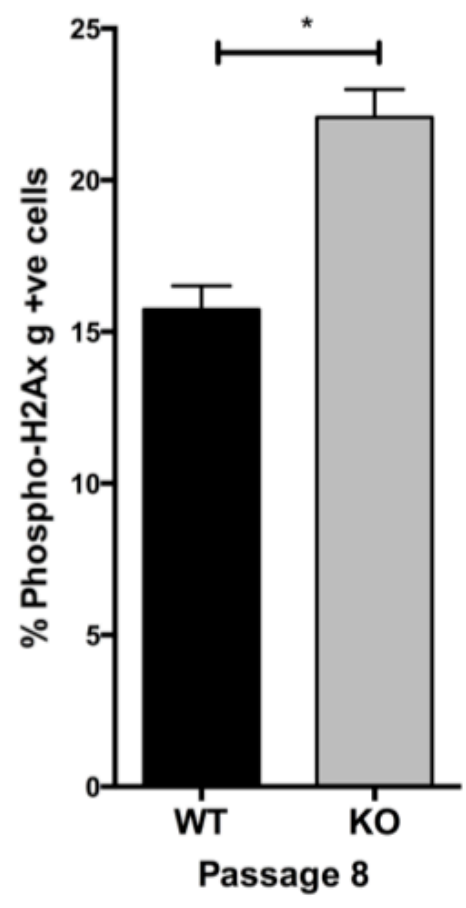

B

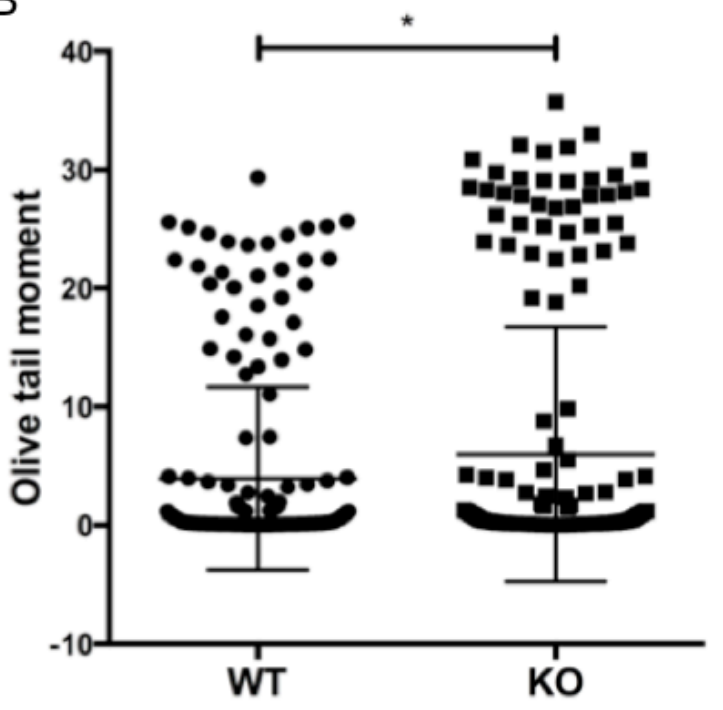

Passage 8

\begin{tabular}{|c|c|}
\hline & Mean +/- SEM \\
\hline WT & $3.962 \pm 0.5453 \mathrm{~N}=200$ \\
\hline KO & $6.001 \pm 0.7600 \mathrm{~N}=200$ \\
\hline
\end{tabular}

Figure 6: Increased DNA damage in MEFs lacking Gadd45b. A. Numbers of phosphorylated Histone $H 2 A X$ (Ser-139) positive cells in $\mathrm{Gadd}_{45 b^{+/+}}(\mathrm{WT})$ and $\mathrm{Gadd} 45 b^{-/}$(KO) MEFs cultured at 21\% oxygen (passage 8) using phosphor-specific anti-Histone $H 2 A X$ (Ser-139) antibodies. Mean values from three independent experiments are shown. B. Dot plot showing DNA comet olive tail moment of

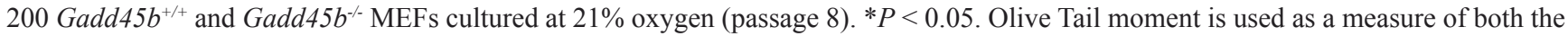
smallest detectable size of migrating DNA (reflected in the comet tail length) and the number of relaxed/broken pieces (represented by the intensity of DNA in the tail). All results shown are the mean of three independent experiments \pm s.e.m.

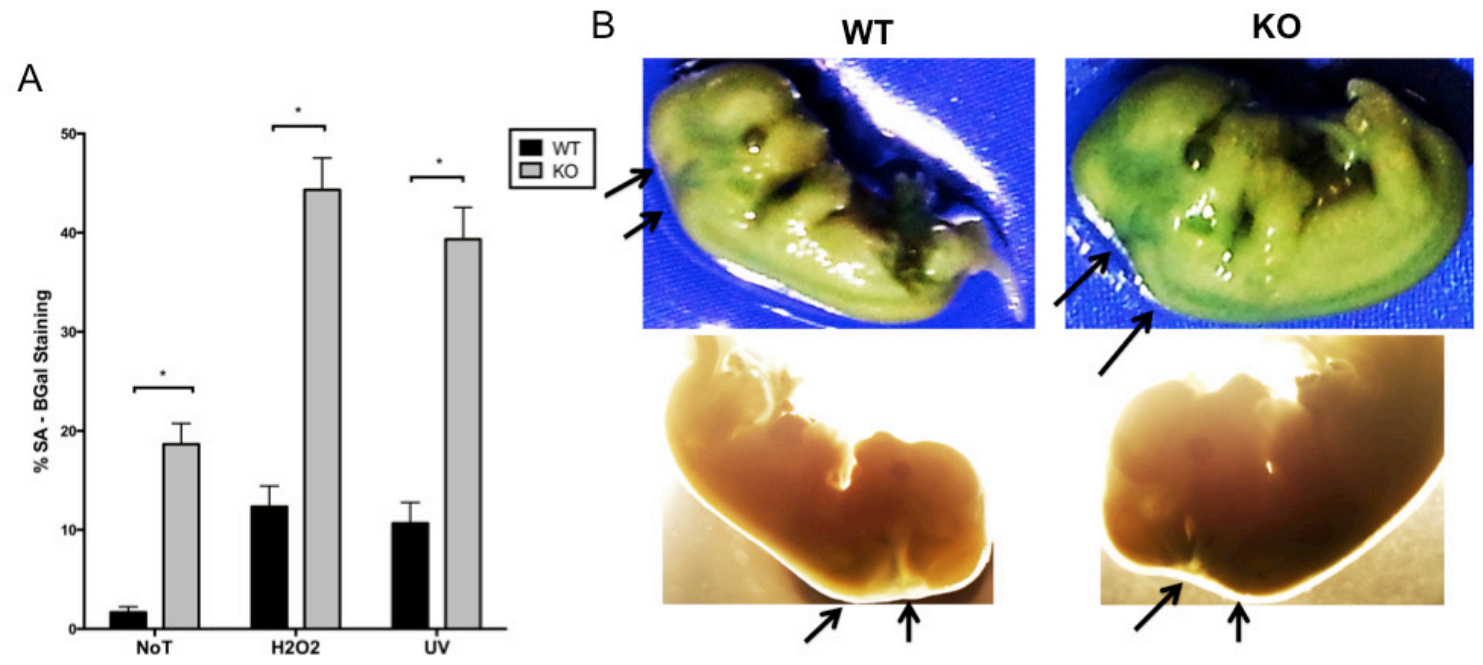

Figure 7: Increased senescence of $\mathbf{G a d d 4 5}^{-/-}$mice is not restricted to tissue culture associated stress. A. Gadd45b $\mathrm{b}^{+/+}(\mathrm{WT}$ -

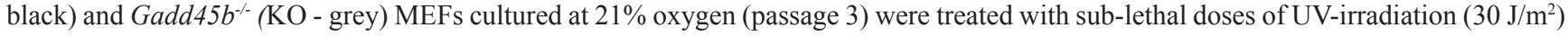
or H2O2 (150 uM). Stress-induced senescence (mean numbers of SA- $\beta$-gal -positive cells) was determined 7 days after stress. $* P<0.05$. B. Photograph of SA- $\beta$-gal staining of $G a d d 45 b^{+/+}$and $G a d d 45 b^{-/}$E14 embryos. Arrows indicate embryonic regions with strong senescence staining. Strong staining was found in the head and neck regions of all mutant embryos tested $(n=6)$. 
The increased senescence resulting from Gadd45b deficiency is not restricted to tissue culture associated stress

Given that environmental stressors such as UV irradiation and oxidative stress have been shown to trigger premature senescence [34], we were interested to determine the effect of these stressors on Gadd $45 b^{-1-}$ MEFs . Early passage Gadd $45 b^{+/+}$and Gadd $45 b^{-/}$MEFs were treated with sub-lethal doses of hydrogen peroxide or UV light. As shown in Figure 7A, an increase in SA- $\beta$ gal staining in Gadd $45 b^{-/}$MEFs compared to Gadd $45 b^{+/+}$ MEFs was observed for cells treated with either UV or hydrogen peroxide, further confirming that loss of Gadd $45 b$ leads to an increase in senescence in response to environmental stress. To investigate whether Gadd45b deficiency enhanced senescence in vivo, we treated E14 embryos from Gadd $45 b^{+/+}$and Gadd $45 b^{-/}$mice with SA$\beta$-gal stain. It is shown that $G a d d 45 b^{-/}$embryos have increased senescence staining compared to embryos from $\mathrm{Gadd}_{4} 5 \mathrm{~b}^{+/+}$mice (Figure 7B), thereby providing in vivo evidence that loss of Gadd $45 \mathrm{~b}$ leads to increased senescence.

\section{Gadd45b deficiency promotes cellular senescence and accelerated aging in mouse skin}

Given the critical role that senescence plays in aging, it was of interest to expand our research on the role of Gadd $45 b$ in aging using mouse skin as an in vivo model

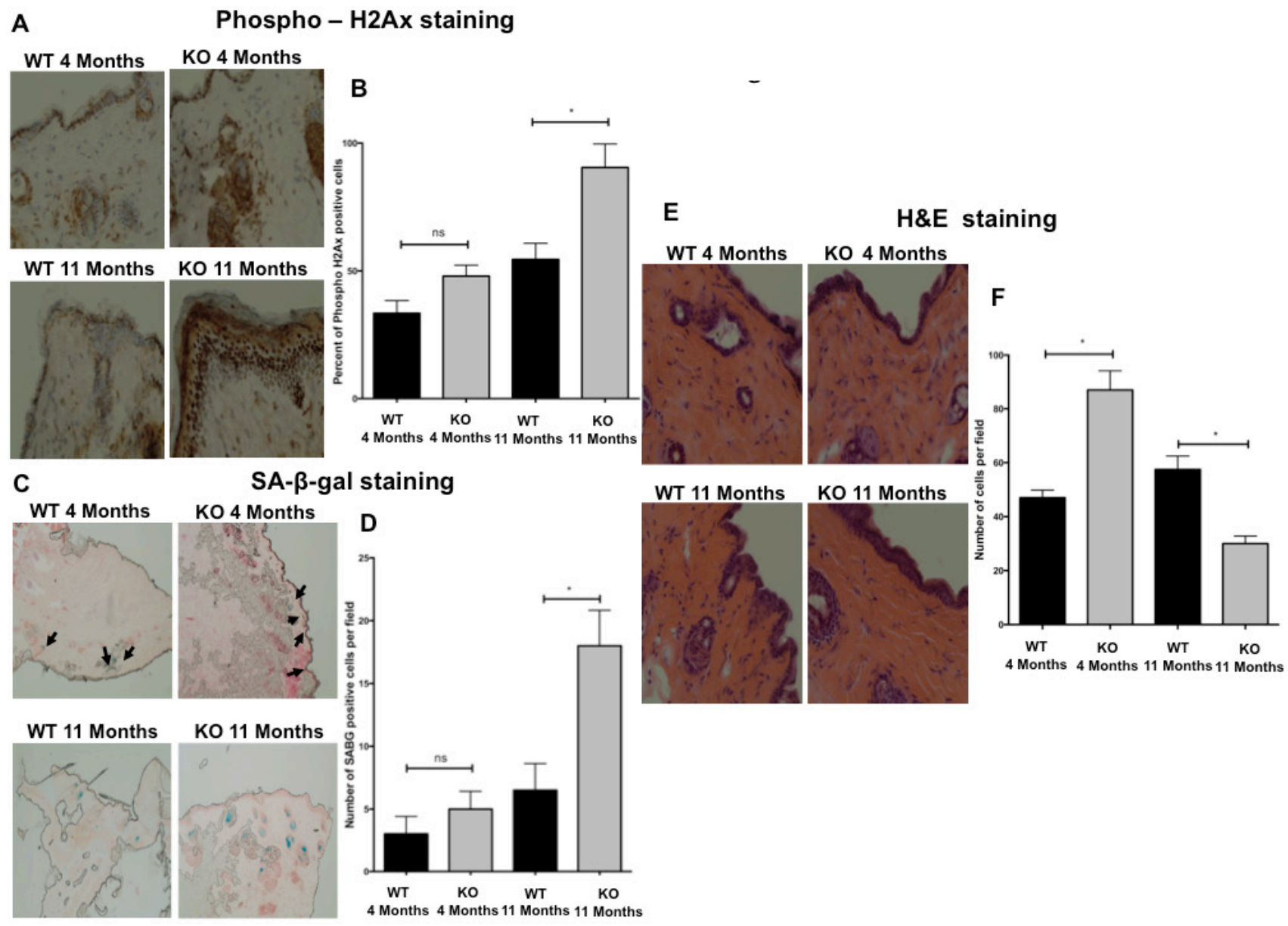

Figure 8: Loss of Gadd45b promotes senescence and aging phenotypes in the skin. A. Representative photomicrographs of immuno-histochemical analysis of phosphorylated histone $\mathrm{H} 2 \mathrm{AX}(\gamma \mathrm{H} 2 \mathrm{AX})$ staining of dorsal skin sections from 4 month and 11-monthold $\mathrm{Gadd}_{45} b^{+/+}(\mathrm{WT})$ and Gadd45b- $(\mathrm{KO})$ mice. B. A quantification of phosphorylated histone $\mathrm{H} 2 \mathrm{AX}(\gamma \mathrm{H} 2 \mathrm{AX})$ staining of $\mathrm{Gadd} 45 b^{+/+}$ (black) and Gadd45 $b^{-/}$(grey) mice is shown. ${ }^{*} P<0.05$. C. Representative photomicrographs of SA- $\beta$-gal staining analysis of dorsal skin sections from 4 month and 11-month-old Gadd45b $b^{+/+}$and Gadd45b $b^{-/}$mice. Arrows indicate skin sections with strong senescence staining. D. A quantification of SA- $\beta$-gal staining of $G a d d 45 b^{+/+}$(black) and Gadd $45 b^{-/}$(grey) mice is shown. $* P<0.05$. E. Representative photomicrographs of histopathological analysis using H\&E staining of dorsal skin sections from 4 month and 11-month-old Gadd45b $b^{+/+}$ and Gadd $45 b^{-/}$mice. F. A quantification of purple stained cells in the skin dermis of Gadd $45 b^{+/+}$(black) and Gadd $45 b^{-/}$(grey) mice is shown. $* P<0.05$. 
system.

To investigate the role of Gadd45b in DNA damage and aging in skin, dorsal skin sections of 4 month and 11-month-old Gadd45b $b^{+/+}$and Gadd45b/ mice were subjected to immuno-histochemical and histopathological analysis. Immuno-histochemical analysis of the well-established marker phosphorylated histone $\mathrm{H} 2 \mathrm{AX}(\gamma \mathrm{H} 2 \mathrm{AX})[35,36]$ was performed to score skin sections for nuclear DNA double-strand breaks. While skin sections from 4 month old Gadd $45 b^{--}$mice showed a slight increase in the number of phospho- histone H2AX $(\gamma \mathrm{H} 2 \mathrm{AX})$ stained cells, skin sections from 11 month old Gadd $45 b^{-/-}$mice showed a significant increase in the number of phospho- histone $\mathrm{H} 2 \mathrm{AX}(\gamma \mathrm{H} 2 \mathrm{AX})$ stained cells compared with their wild type counterparts (Figure 8A and 8B) indicating that Gadd45b deficiency leads to increased DNA double-strand breaks in the skin in vivo. In order to further characterize this aging phenotype and analyze the role of Gadd45b in modulating senescence in aging skin, senescence associated beta gal staining was carried out. While skin sections from 4 month old Gadd $45 b^{-/}$mice showed a slight increase in the number of senescence associated beta gal stained cells, skin sections from 11 month old Gadd45 $b^{-/}$mice showed a significant increase in the number of senescence associated beta gal stained cells in the skin dermis (Figure 8C and 8D) compared with their wild type counterparts. Given that DNA damage and senescence play a critical role in the aging of skin, the effect of Gadd45b deficiency on skin aging was investigated by histopathological analysis using H\&E staining. While skin sections from 4-monthold $G a d d 45 b^{-/}$mice showed higher number of cells in the dermis, skin sections from 11 month old Gadd $45 b^{-/}$mice showed a significant decrease in the number of cells in the dermis (Figure 8E and 8F), compared with their wild type counterparts. Dermal cellularity has been shown to be an essential aging phenotype in skin [37-39]. Thus, taken together, these data indicate that Gadd45b deficiency promotes enhanced cellular senescence and DNA damage, as well as a phenotype associated with more advanced aging in skin.

\section{DISCUSSION}

The current study highlights a novel role for Gadd45b in the senescence response of mouse fibroblasts to oxidative stress, taking advantage of Gadd $45 b^{-/}$mice. Our results show that Gadd45b is critical for MEF proliferation and $\mathrm{G} 2 / \mathrm{M}$ cell-cycle progression under hyperoxic conditions, since loss of Gadd45b leads to premature senescence, defective proliferation and reduced Cdc2 expression. Thus, it seems that under conditions of environmental stress, Gadd $45 \mathrm{~b}$ might function to limit the senescence response and maintain the proliferative state of the cells.

As it is known that senescence in MEFs is associated with p19 Arf $-p 53-p 21$ signaling, we next investigated the expression of these critical cell cycle regulators. Our results show that Gadd45b/- MEFs have increased levels of p16, p19 ${ }^{\mathrm{ARF}}, \mathrm{p} 21$ and p53 proteins at earlier passage compared to Gadd45 $b^{+/+}$MEFs. Interestingly, despite the increased expression of critical senescence proteins in Gadd45b/- MEFs, these cells do not undergo G1 arrest but rather G2 arrest. It was observed that $\mathrm{Gadd}_{45} \mathrm{~b}^{-/}$MEFs accumulated DNA damage, and it is hypothesized that this occurred in the $\mathrm{S}$ phase leading to activation of the G2 checkpoint and cells arresting with G2 DNA content. Previous studies have shown that $M k k 7$ - MEFs and $c J u n^{-\alpha}$ MEFs have impaired proliferation, premature senescence and a G/2M cell-cycle arrest. The G2/M kinase Cdc2 was identified as a molecular target for the MKK7-JNK-cJun-signaling pathway [40, 21]. Given that Gadd45b is associated with the MKK7-JNKcJun pathway, and Gadd45 $b^{-/}$MEFs arrest at G2/M, we studied the expression levels of Cdc2. Interestingly, similar to $\mathrm{Mkk}^{-/-}$MEFs and $\mathrm{cJun}^{-/}$MEFs, Gadd45 $b^{-/-}$ MEFs showed decreased $\mathrm{Cdc} 2$ expression indicating that Gadd45b engages the MKK7-JNK-cJun pathway in regulating senescence. Interestingly, blocking JNK activity with the JNK inhibitor SP600125 at passage 6 showed only a modest decrease in SA- $\beta$-gal staining. However, it should be pointed out that there is a gradual increase in the senescent cell population with increasing passage number (Figure 1), consistent with JNK inhibition leading to a decrease only in newly senescing cell populations but having no effect on the pre-existing senescent cells.

Similarities between the senescence phenotype of Gadd45b $b^{-/}$MEFs and MEFs deficient for genes involved in DNA damage pathways suggested that growth arrest in Gadd45b/- MEFs might be attributable to DNA damage accumulation. To test this, we cultured Gadd45 $b^{-/}$MEFs under conditions which limit oxidative DNA damage, the major environmental insult cells experience during conventional culture conditions [19]. Our results show that culturing cells under more physiological oxygen conditions results in partial rescue of their ability to proliferate, thereby demonstrating that Gadd $45 b^{-/}$MEFs have increased sensitivity to oxidative stress. It should be noted that $\mathrm{Gadd}_{45} \mathrm{~b}^{+/+} \mathrm{MEFs}$ also proliferated better in $3 \%$ oxygen; however, there was still a difference between Gadd $45 b^{+/+}$and Gadd45b/- MEFs. Both Gadd45b $b^{+/+}$and $\mathrm{Gadd}_{45} \mathrm{~b}^{-/}$MEFs had high levels of DNA damage and $\mathrm{gH} 2 \mathrm{AX}$-containing repair foci in their nuclei, but the number of repair foci and the amount of DNA damage were significantly higher in the Gadd45 $b^{-/}$MEFs. Previous reports have shown that normal mouse cell senescence occurs as a consequence of the accumulation of DNA damage resulting from hyperoxic culture conditions [20-21]. Our data provide an important extension of this notion, showing for the first time that Gadd45b plays a critical role in protecting MEFs from oxidative stress and limiting the DNA damage and senescence response. In 
addition to oxidative stress, other environmental stresses such as UV irradiation and hydrogen peroxide also trigger premature senescence in Gadd45 $b^{-/-}$MEFs compared to Gadd $45 b^{+/+}$MEFs.

Interestingly, increased senescence was observed in E14 embryos from Gadd45 $b^{-/}$mice compared to wild type providing in vivo evidence for increased senescence in Gadd45b $b^{-/}$mice. Given that the temporal expression patterns of Gadd45 genes are dynamic and differential during mouse embryonic development [41] it is hypothesized that Gadd45b might function to limit the senescence response to various stimulants involved in embryonic development, a response that is compromised in $\mathrm{Gadd}_{45} \mathrm{~b}^{-/}$mice leading to increased senescence. Furthermore, transgenic mice for tamoxifen-induced Dicer ablation [42] as well as hypomorphic mutation of Brcal (Brcal $11 / \Delta 11)$ [43], genes that regulate DNA damage [44], also showed increased senescence staining in mutant embryos compared to wild type. While this work was in progress, two landmark studies found evidence for the presence of senescent cells in mouse and human embryos showing that senescence is a normal programmed mechanism that plays instructive roles in tissue remodeling and development [45-46]. They identified non-dividing SA- $\beta$-gal-containing cells in different regions of the embryo that also expressed high levels of $\mathrm{p} 21$. It will therefore be interesting to further investigate the senescence- limiting effect of Gadd45b on normal embryonic development, characterize the senescence distribution among different tissues in the embryos and analyze the senescence pattern during the various stages of embryonic development.

We also show that loss of Gadd $45 \mathrm{~b}$ promotes aging phenotypes in mouse skin including increased DNA damage, increased senescence and decreased dermal cellularity. Similar aging phenotypes have been reported previously, including mice with chronic activation of $\mathrm{p} 53$ (p53 ${ }^{\mathrm{TSD} /}$ mice with two phosphomimetic mutations (T21D and S23D) [47], Sod2 deficient mice [48] and Mdm2 deficient mice [49]. It will be of interest to determine whether there is crosstalk between Gadd45b regulated molecular pathways that prevent premature aging and molecular pathways regulated by these other proteins.

Finally, our findings raise several interesting questions warranting further investigation: These include: how Gadd45b regulates senescence driven by other stressors; how Gadd45b interfaces with different signaling pathways in response to distinct stressors; what role Gadd45b expression or the lack of it plays in the senescence response of human cells; what is the effect of loss of Gadd45b on aging in other organs and the entire mouse life span; and do other Gadd45 genes (i.e., Gadd45a and Gadd45g), either separately or in combination with Gadd45b, regulate stress induced senescence. Several other genes including Mkk7 [40], cJun [21], Brcal [43], Id1 [50], Hus1 [51], Jnk [31], Ku80
[52], Polmu [53], Vhl [54], Dicer [42] and TGF $\beta$ [20] have been observed to limit tissue culture-induced senescence similar to Gadd45b, where their loss resulted in premature senescence. Thus, it is of interest to determine whether there is crosstalk between Gadd45b regulated molecular pathways that protect cells from undergoing tissue cultureinduced senescence and molecular pathways regulated by these other proteins. Notably, the observation that Gadd45b loss results in premature senescence is in contrast to Gadd45a KO MEFs that were observed to escape senescence (Unpublished data). Thus, it will also be of interest to compare and contrast Gadd45b signaling to Gadd45a signaling in MEFs, where loss of Gadd45a results in escape from tissue cultured senescence. Current research is targeted at addressing these interesting issues.

In conclusion, the results obtained indicate that GADD45 proteins differentially modulate stress- and tissue culture-induced cellular senescence, providing the impetus to further investigate the role of GADD45 proteins in senescence under normal physiological conditions as well as various pathological conditions.

\section{MATERIALS AND METHODS}

\section{Animals}

Mice were maintained in a temperature and humidity-controlled environment at Temple University's Health Science campus animal facilities following the guidelines of Institutional Animal Care and Use Committee (IACUC) of Temple University. Mice genotype was confirmed by PCR using specific primer sets for Gadd $45 b$ and the neomycin phosphotransferase reporter gene each time the litters were produced. MEFs were obtained from 13.5-day WT or Gadd45b - $^{-\alpha}$ sibling embryos.

\section{Cell culture}

MEFs were grown in Dulbecco's modified Eagle's medium (DMEM) supplemented with 10\% fetal bovine serum in $3 \% \mathrm{O}_{2} / 5 \% \mathrm{CO}_{2}$ for 2 days, then harvested, viably frozen, and labeled as passage 0. For 3T3 assays, MEFs were seeded at $3 \times 10^{5}$ cells per $10 \mathrm{~cm}$ plate, trypsinized after three days, counted and re-seeded at the same density. For growth at low oxygen levels, MEFs were grown in a humidified hypoxia chamber that was flooded with a gas mixture of $92 \%$ Nitrogen, 3\% Oxygen, 5\% Carbon Dioxide. Cells were counted in triplicate. The number of cells obtained on day3 (N3) was divided by the initial cell number $\left(\mathrm{N} 0=3 \times 10^{5}\right)$ and plotted as growth rate $(\mathrm{N} 3 / \mathrm{N} 0)$. The increase in the population doubling level $(\triangle \mathrm{PDL})$ was calculated according to the following formula: $\triangle \mathrm{PDL}=$ $\log (\mathrm{Nf} / \mathrm{N} 0) / \log 2$, where $\mathrm{N} 0$ is the initial number of cells 
$\left(3 \mathrm{X} 10^{5}\right)$ and $\mathrm{Nf}$ is the final number of cells.

\section{UV irradiation and hydrogen peroxide treatment}

UV irradiation ( $50 \mathrm{~J} / \mathrm{m} 2)$ of cells was carried out with a Stratalinker (Fisher Scientific) adjusted to UV-C irradiation. The cells were washed with phosphatebuffered saline before irradiation in the absence of any medium. Following irradiation, cells were supplemented with culture medium for 7 days and analyzed for SA- $\beta$ gal activity. Oxidative stress was induced by sub-cytotoxic levels of hydrogen peroxide ( $150 \mu \mathrm{M}$ for 4 hours $)$ and then cells were recovered in normal medium for 7 days and analyzed for SA- $\beta$-gal activity.

\section{Senescence-associated $\beta$-galactosidase (SA- $\beta$-gal) assay}

Senescent cells were detected by staining for beta-gal using X-Gal (Cell Signaling, Danvers, MA). Stained cells were visualized using an Olympus inverted microscope with digital imaging (Leica MZ16 stereomicroscope) and images were captured with a QImaging 5.0 RTV digital camera. A total of 300-400 cells were evaluated to assess the percentage of SA- $\beta$ Gal positive cells. Similarly, whole-mount embryo SA- $\beta$ Gal was also detected following overnight fixation and incubation with X-gal for 4-6 h.

\section{Western blotting}

Cells were incubated in cell lysis buffer (no. 9803; Cell Signaling Technology, Danvers, MA) followed by centrifugation at $13,000 \mathrm{rpm}$ for 10 minutes. Supernatants were collected, and protein concentrations were determined using the Bradford Assay (Bio-Rad, Hercules, CA). Protein lysates were electrophoresed on Tris-glycine SDS polyacrylamide gels and transferred onto Immobilon-P membrane. Incubation with antibodies was performed according to Cell Signaling Technologyrecommended procedures and proteins were visualized using ECL (Pierce). p16 ${ }^{\text {Ink4A }}$, p19 ${ }^{\mathrm{ARF}}, \mathrm{p} 21$, Total-p53, cdc2 were from Abcam. Phospho-p53(Ser15), Cyclin B1, Phospho-SAPK/JNK(Thr183/Tyr185), Total-SAPK/JNK and $\beta$-Actin were from Cell Signaling Technology.

\section{RNA extraction and quantitative polymerase chain reaction}

RNA was extracted from samples using RNeasy kit (Qiagen) according to manufacturer's protocol. Reverse transcriptase polymerase chain reaction (RT-PCR) was performed to convert RNA to c-DNA using TaqMan Reverse Transcription reagents (Applied Bio systems) according to manufacturer's protocol. c-DNA was then used to run the real time polymerase chain reaction analysis (qRT-PCR) in a StepOne Real Time PCR machine (Applied Bio systems). Taqman probes used for this study, purchased from Life Technologies, are the following: Mm00435123 m1 (mouse Gadd45b), and Mm04277571 $\mathrm{S} 1$, for $18 \mathrm{~s}$, used as an endogenous control.

\section{Flow cytometric cell cycle analysis}

Cells were collected at the indicated time points and fixed in methanol. Prior to analysis, cells were treated with a solution containing $10 \%$ propidium iodide (500 $\mu \mathrm{g} / \mathrm{ml}), 5 \mathrm{mg} / \mathrm{ml} \mathrm{10 \%}$ RNase A and $80 \% 1 \times$ phosphatebuffered saline (PBS) plus $1 \% \mathrm{FBS}$, and incubated at $37^{\circ} \mathrm{C}$ for $30 \mathrm{~min}$. The cells were analyzed with a FACSCalibur (BD) flow cytometer, and the data were analyzed using FlowJo analysis software (Tree Star). To determine cell cycle distributions in the G2 and M phases, cells were harvested with trypsin, stained using anti phosphohistone H3 - AlexaFluor ${ }^{\circledR} 488$ antibody on ice for one hour in the dark, followed by staining using PI/RNase solution for 30 minutes at room temperature in the dark per the manufacturer's instructions (\#FCCH025103, EMD Millipore Corporation, Ballerica, MA). The samples were analyzed by a FACScan flow cytometer (BectonDickinson), with FlowJo analysis software (Tree Star).

\section{Immunofluorescence and mitotic index analysis}

Hoechst 33342 stock solution (Molecular Probes) was diluted 1:100 in $\mathrm{H}_{2} \mathrm{O}$. The medium was aspirated from cells grown on cover slips and the cells were rinsed three times with PBS. The cells were incubated in the diluted Hoechst solution for $15 \mathrm{~min}$ at room temperature. After labeling, cells were washed with PBS and imaged under an EVOSTM Digital Inverted Fluorescence Microscope. The mitotic index, i.e., the percentage of cells in mitosis was determined by counting at least 300 cells in three independent experiments. The mitotic index was determined by fluorescence microscopic analysis of Hoechst 33342 stained nuclear morphology.

\section{Alkaline comet assays}

Comet assays were performed using the Trevigen Comet Assay Kit (4250-050-K) as per the manufacturer's instructions. Cells (1000) were mixed with low melt agarose, spotted onto slides, lysed, and electrophoresed under denaturing conditions at 4 degree C. DNA was stained with SYBR green and images were captured at 20x magnification using an EVOSTM Digital Inverted Fluorescence Microscope. Images were saved as bitmap files and olive tail moments were calculated using TriTek 
CometScoreTM Freeware v1.5.

\section{Histo-pathological and immuno-histochemical evaluation of skin samples}

Dorsal skin samples from euthanized mice were fixed in $10 \%$ buffered formalin for $24 \mathrm{~h}$, transferred to $70 \%$ ethanol, embedded in paraffin, and sliced. The sections were stained with hematoxylin and eosin (H\&E) for histological assessment.

Optimal Cutting Temperature compound (OCT)embedded samples were cut into $10 \mu \mathrm{m}$ sections. Sections were fixed in $10 \%$ buffered formalin, permeabilized with $0.5 \%$ triton-X, blocked with $4 \%$ donkey serum $/ 1 \%$ BSA in PBS solution and incubated with anti- $\gamma \mathrm{H} 2 \mathrm{AX}$ (NB10079967, Novus Biologicals, 1:500) overnight at $4^{\circ} \mathrm{C}$, followed by incubation with Alexa 555 donkey anti-rabbit (Invitrogen, 1:750) for $1 \mathrm{~h}$ at room temperature. Sections were mounted with Prolong Gold with DAPI (Invitrogen).

OCT-embedded skin sections were processed for SA- $\beta$-gal staining using Senescence Detection Kit (BioVision, Mountain View, CA, USA). Sections were counterstained with nuclear fast red and visualized by brightfield microscopy.

\section{Statistical analysis}

Data are presented as mean \pm s.e.m. Unless indicated all analyses were done by using Student's t test $* P<0.05$, $* * P<0.01$ and $* * * P<0.001$.

\section{ACKNOWLEDGMENTS}

This work was supported by the National Institutes of Health 1R01CA122376-01 and a grant from the Pennsylvania Department of Health to D.L. We thank Dr. Xiaoxuan Fan (Temple Flow Cytometry), Dr. Dmitri Gourevitch (Wistar Histopathology), Ms. Cass (Fox Chase Histopathology) for their technical assistance and Dr. Dheeraj Bhavanasi for his critical review of the manuscript.

\section{CONFLICTS OF INTEREST}

The authors declare no conflict of interest.

\section{REFERENCES}

1. Fornace AJ, Jr. Mammalian genes induced by radiation; activation of genes associated with growth control. Annu Rev Genet. 1992; 26:507-526.

2. Beadling $\mathrm{C}$, Johnson $\mathrm{KW}$ and Smith $\mathrm{KA}$. Isolation of interleukin 2-induced immediate-early genes. Proc Natl Acad Sci U S A. 1993; 90:2719-2723.

3. Abdollahi A, Lord KA, Hoffman-Liebermann B and Liebermann DA. Sequence and expression of a cDNA encoding MyD118: a novel myeloid differentiation primary response gene induced by multiple cytokines. Oncogene. 1991; 6:165-167.

4. Zhang W, Bae I, Krishnaraju K, Azam N, Fan W, Smith K, Hoffman B and Liebermann DA. CR6: A third member in the MyD118 and Gadd45 gene family which functions in negative growth control. Oncogene. 1999; 18:4899-4907.

5. Vairapandi M, Balliet AG, Fornace AJ, Jr., Hoffman B and Liebermann DA. The differentiation primary response gene MyD118, related to GADD45, encodes for a nuclear protein which interacts with PCNA and p21WAF1/CIP1. Oncogene. 1996; 12:2579-2594.

6. Vairapandi M, Azam N, Balliet AG, Hoffman B and Liebermann DA. Characterization of MyD118, Gadd45, and proliferating cell nuclear antigen (PCNA) interacting domains. PCNA impedes MyD118 AND Gadd45-mediated negative growth control. J Biol Chem. 2000; 275:1681016819.

7. Salerno DM, Tront JS, Hoffman B and Liebermann DA. Gadd45a and Gadd45b modulate innate immune functions of granulocytes and macrophages by differential regulation of p38 and JNK signaling. J Cell Physiol. 2012; 227:36133620 .

8. Hollander MC, Sheikh MS, Bulavin DV, Lundgren K, Augeri-Henmueller L, Shehee R, Molinaro TA, Kim KE, Tolosa E, Ashwell JD, Rosenberg MP, Zhan Q, FernandezSalguero PM, Morgan WF, Deng CX and Fornace AJ, Jr. Genomic instability in Gadd45a-deficient mice. Nat Genet. 1999; 23:176-184.

9. Takekawa M and Saito H. A family of stress-inducible GADD45-like proteins mediate activation of the stressresponsive MTK1/MEKK4 MAPKKK. Cell. 1998; 95:521530.

10. Vairapandi M, Balliet AG, Hoffman B and Liebermann DA. GADD45b and GADD45g are cdc2/cyclinB1 kinase inhibitors with a role in $\mathrm{S}$ and $\mathrm{G} 2 / \mathrm{M}$ cell cycle checkpoints induced by genotoxic stress. J Cell Physiol. 2002; 192:327338.

11. Liebermann DA and Hoffman B. Gadd45 in stress signaling. J Mol Signal. 2008; 3:15.

12. Papa S, Monti SM, Vitale RM, Bubici C, Jayawardena S, Alvarez K, De Smaele E, Dathan N, Pedone C, Ruvo M and Franzoso G. Insights into the structural basis of the GADD45beta-mediated inactivation of the JNK kinase, MKK7/JNKK2. J Biol Chem. 2007; 282:19029-19041.

13. Papa S, Zazzeroni F, Bubici C, Jayawardena S, Alvarez K, Matsuda S, Nguyen DU, Pham CG, Nelsbach AH, Melis T, De Smaele E, Tang WJ, D'Adamio L and Franzoso G. Gadd45 beta mediates the NF-kappa B suppression of JNK 
signalling by targeting MKK7/JNKK2. Nat Cell Biol. 2004; 6:146-153.

14. Hayflick L. The limited in vivo lifetime of human diploid cell strains. Exp Cell Res. 1965; 37:614-636.

15. Campisi J and d'Adda di Fagagna F. Cellular senescence: when bad things happen to good cells. Nat Rev Mol Cell Biol. 2007; 8:729-740.

16. Ben-Porath I and Weinberg RA. When cells get stressed: an integrative view of cellular senescence. J Clin Invest. 2004; 113:8-13.

17. Collado M, Blasco MA and Serrano M. Cellular senescence in cancer and aging. Cell. 2007; 130:223-233.

18. Sherr CJ and DePinho RA. Cellular senescence: mitotic clock or culture shock? Cell. 2000; 102:407-410.

19. Parrinello S, Samper E, Krtolica A, Goldstein J, Melov $\mathrm{S}$ and Campisi J. Oxygen sensitivity severely limits the replicative lifespan of murine fibroblasts. Nat Cell Biol. 2003; 5:741-747.

20. Zerlanko BJ, Bartholin L, Melhuish TA and Wotton D. Premature senescence and increased TGFbeta signaling in the absence of Tgif1. PLoS One. 2012; 7:e35460.

21. MacLaren A, Black EJ, Clark W and Gillespie DA. c-Jundeficient cells undergo premature senescence as a result of spontaneous DNA damage accumulation. Mol Cell Biol. 2004; 24:9006-9018.

22. Bulavin DV, Kovalsky O, Hollander MC and Fornace AJ, Jr. Loss of oncogenic H-ras-induced cell cycle arrest and p38 mitogen-activated protein kinase activation by disruption of Gadd45a. Mol Cell Biol. 2003; 23:3859-3871.

23. Tront JS, Hoffman B and Liebermann DA. Gadd45a suppresses Ras-driven mammary tumorigenesis by activation of c-Jun NH2-terminal kinase and p38 stress signaling resulting in apoptosis and senescence. Cancer Res. 2006; 66:8448-8454.

24. Tront JS, Huang Y, Fornace AJ, Jr., Hoffman B and Liebermann DA. Gadd45a functions as a promoter or suppressor of breast cancer dependent on the oncogenic stress. Cancer Res. 2010; 70:9671-9681.

25. Roy N, Stoyanova T, Dominguez-Brauer C, Park HJ, Bagchi S and Raychaudhuri P. DDB2, an essential mediator of premature senescence. Mol Cell Biol. 2010; 30:26812692.

26. Takeuchi S, Takahashi A, Motoi N, Yoshimoto S, Tajima T, Yamakoshi K, Hirao A, Yanagi S, Fukami K, Ishikawa Y, Sone S, Hara E and Ohtani N. Intrinsic cooperation between p16INK4a and p21Waf1/Cip1 in the onset of cellular senescence and tumor suppression in vivo. Cancer Res. 2010; 70:9381-9390.

27. Sherwood SW, Rush D, Ellsworth JL and Schimke RT. Defining cellular senescence in IMR-90 cells: a flow cytometric analysis. Proc Natl Acad Sci U S A. 1988; 85:9086-9090.

28. Lake RS and Salzman NP. Occurrence and properties of a chromatin-associated F1-histone phosphokinase in mitotic
Chinese hamster cells. Biochemistry. 1972; 11:4817-4826.

29. Kuilman T, Michaloglou C, Mooi WJ and Peeper DS. The essence of senescence. Genes Dev. 2010; 24:2463-2479.

30. Arion D, Meijer L, Brizuela L and Beach D. cde2 is a component of the $\mathrm{M}$ phase-specific histone $\mathrm{H} 1$ kinase: evidence for identity with MPF. Cell. 1988; 55:371-378.

31. Das M, Jiang F, Sluss HK, Zhang C, Shokat KM, Flavell RA and Davis RJ. Suppression of p53-dependent senescence by the JNK signal transduction pathway. Proc Natl Acad Sci U S A. 2007; 104:15759-15764.

32. Baus F, Gire V, Fisher D, Piette J and Dulic V. Permanent cell cycle exit in G2 phase after DNA damage in normal human fibroblasts. EMBO J. 2003; 22:3992-4002.

33. Siliciano JD, Canman CE, Taya Y, Sakaguchi K, Appella $\mathrm{E}$ and Kastan MB. DNA damage induces phosphorylation of the amino terminus of p53. Genes Dev. 1997; 11:34713481 .

34. Toussaint O, Dumont P, Dierick JF, Pascal T, Frippiat C, Chainiaux F, Sluse F, Eliaers F and Remacle J. Stressinduced premature senescence. Essence of life, evolution, stress, and aging. Ann N Y Acad Sci. 2000; 908:85-98.

35. Rogakou EP, Pilch DR, Orr AH, Ivanova VS and Bonner WM. DNA double-stranded breaks induce histone H2AX phosphorylation on serine 139. J Biol Chem. 1998; 273:5858-5868.

36. Lobrich M, Shibata A, Beucher A, Fisher A, Ensminger M, Goodarzi AA, Barton O and Jeggo PA. gammaH2AX foci analysis for monitoring DNA double-strand break repair: strengths, limitations and optimization. Cell Cycle. 2010; 9:662-669.

37. Varani J, Warner RL, Gharaee-Kermani M, Phan SH, Kang S, Chung JH, Wang ZQ, Datta SC, Fisher GJ and Voorhees JJ. Vitamin A antagonizes decreased cell growth and elevated collagen-degrading matrix metalloproteinases and stimulates collagen accumulation in naturally aged human skin. J Invest Dermatol. 2000; 114:480-486.

38. Farage MA, Miller KW, Elsner $\mathrm{P}$ and Maibach HI. Characteristics of the Aging Skin. Adv Wound Care (New Rochelle). 2013; 2:5-10.

39. Tiganescu A, Tahrani AA, Morgan SA, Otranto M, Desmouliere A, Abrahams L, Hassan-Smith Z, Walker EA, Rabbitt EH, Cooper MS, Amrein K, Lavery GG and Stewart PM. 11beta-Hydroxysteroid dehydrogenase blockade prevents age-induced skin structure and function defects. J Clin Invest. 2013; 123:3051-3060.

40. Wada T, Joza N, Cheng HY, Sasaki T, Kozieradzki I, Bachmaier K, Katada T, Schreiber M, Wagner EF, Nishina $\mathrm{H}$ and Penninger JM. MKK7 couples stress signalling to G2/M cell-cycle progression and cellular senescence. Nat Cell Biol. 2004; 6:215-226.

41. Kaufmann LT, Gierl MS and Niehrs C. Gadd45a, Gadd45b and Gadd45g expression during mouse embryonic development. Gene Expr Patterns. 2011; 11:465-470.

42. Mudhasani R, Zhu Z, Hutvagner G, Eischen CM, Lyle S, 
Hall LL, Lawrence JB, Imbalzano AN and Jones SN. Loss of miRNA biogenesis induces p19Arf-p53 signaling and senescence in primary cells. J Cell Biol. 2008; 181:10551063.

43. Cao L, Li W, Kim S, Brodie SG and Deng CX. Senescence, aging, and malignant transformation mediated by p53 in mice lacking the Brcal full-length isoform. Genes Dev. 2003; 17:201-213.

44. Deng CX and Brodie SG. Roles of BRCA1 and its interacting proteins. Bioessays. 2000; 22:728-737.

45. Munoz-Espin D, Canamero M, Maraver A, Gomez-Lopez G, Contreras J, Murillo-Cuesta S, Rodriguez-Baeza A, Varela-Nieto I, Ruberte J, Collado M and Serrano M. Programmed cell senescence during mammalian embryonic development. Cell. 2013; 155:1104-1118.

46. Storer M, Mas A, Robert-Moreno A, Pecoraro M, Ortells MC, Di Giacomo V, Yosef R, Pilpel N, Krizhanovsky V, Sharpe J and Keyes WM. Senescence is a developmental mechanism that contributes to embryonic growth and patterning. Cell. 2013; 155:1119-1130.

47. Kim J, Nakasaki M, Todorova D, Lake B, Yuan CY, Jamora $\mathrm{C}$ and $\mathrm{Xu} \mathrm{Y}$. p53 Induces skin aging by depleting Blimp1+ sebaceous gland cells. Cell Death Dis. 2014; 5:e1141.

48. Velarde MC, Flynn JM, Day NU, Melov S and Campisi J. Mitochondrial oxidative stress caused by Sod 2 deficiency promotes cellular senescence and aging phenotypes in the skin. Aging (Albany NY). 2012; 4:3-12. doi: 10.18632/ aging. 100423 .
49. Gannon HS, Donehower LA, Lyle S and Jones SN. Mdm2-p53 signaling regulates epidermal stem cell senescence and premature aging phenotypes in mouse skin. Dev Biol. 2011; 353:1-9.

50. Alani RM, Young AZ and Shifflett CB. Id1 regulation of cellular senescence through transcriptional repression of p16/Ink4a. Proc Natl Acad Sci U S A. 2001; 98:7812-7816.

51. Levitt PS, Zhu M, Cassano A, Yazinski SA, Liu H, Darfler J, Peters RM and Weiss RS. Genome maintenance defects in cultured cells and mice following partial inactivation of the essential cell cycle checkpoint gene Hus1. Mol Cell Biol. 2007; 27:2189-2201.

52. Lim DS, Vogel H, Willerford DM, Sands AT, Platt KA and Hasty P. Analysis of ku80-mutant mice and cells with deficient levels of p53. Mol Cell Biol. 2000; 20:3772-3780.

53. Lucas D, Escudero B, Ligos JM, Segovia JC, Estrada JC, Terrados G, Blanco L, Samper E and Bernad A. Altered hematopoiesis in mice lacking DNA polymerase mu is due to inefficient double-strand break repair. PLoS Genet. 2009; 5:e1000389.

54. Welford SM, Dorie MJ, Li X, Haase VH and Giaccia AJ. Renal oxygenation suppresses VHL loss-induced senescence that is caused by increased sensitivity to oxidative stress. Mol Cell Biol. 2010; 30:4595-4603. 